\title{
Long-term Observations on the Molting of a Japanese Toad, Bufo japonicus formosus
}

\author{
TATSUYA TANAKA
}

\begin{abstract}
Four adult toads were kept under outdoor conditions for nine years in order to observe molting behavior. Between spring and autumn, the intervals between molting shortened when the temperature was high. The intervals were shorter in females than in males. The periods between molting lengthened as the toads aged. The molting occurred more frequently on days with increased relative humidity change. Molting most often occurred between $1500 \mathrm{~h}$ and $2100 \mathrm{~h}$. The toads molted two or three times during hibernation. Another observation on one-year-old toads showed that they molted much more frequently.
\end{abstract}

Key words: Bufo japonicus formosus; Molting; Aging

Up to the present, numerous observations and experiments have been conducted on molting in toads (Dickerson, 1906; Taylor and Ewer, 1956; Scharrer, 1958; Jørgensen and Larsen, 1961; Jørgensen and Larsen, 1964; Stefano and Donoso, 1964; Larsen, 1976; Budtz, 1977). But all these studies have been undertaken during short periods and under laboratory conditions. I reared toads in field conditions, and the observation continued for more than ten years. The molting behavior of the same four individuals was observed over a nine yr period, and molting during hibernation was recorded.

\section{Materials and Methods}

Animals.-The toads, Bufo japonicus formosus, were raised in a private garden in Katsunuma, Yamanashi Prefecture $\left(35^{\circ} 40^{\prime} \mathrm{N}\right.$, $138^{\circ} 44^{\prime} \mathrm{E}$, altitude $400 \mathrm{~m}$ ), where they naturally spawned, spent the larval period, metamorphosed, and grew up. Four four-yr-old toads, 10.2$13.4 \mathrm{~cm}$ in body length, which had just begun reproductive activity, were used from 1984 to 1992. Two of them were males and the others were females. In addition, four one-yr-old toads, $3.0-3.8 \mathrm{~cm}$ in body length, and unsexed externally, were also used in 1988.

Rearing method.-The adult toads were kept in a wooden box $150 \mathrm{~cm} \times 70 \mathrm{~cm} \times 70 \mathrm{~cm}$ without a bottom. The box was set into the ground so that $30 \mathrm{~cm}$ protruded above the ground. The box was filled to a depth of $40 \mathrm{~cm}$ with a mixture of dirt, sand, and fallen leaves, and covered with a removable wire-mesh lid. For winter, a

Accepted 21 Mar. 1995 wooden box $130 \mathrm{~cm} \times 70 \mathrm{~cm} \times 70 \mathrm{~cm}$ with small holes punched in the bottom was used. The box was set $50 \mathrm{~cm}$ into the ground, and was filled to $50 \mathrm{~cm}$ with dirt, sand, and fallen leaves, with a $10 \mathrm{~cm}$ layer of leaves and straw over this. The lid was filled with fine-grained polystyrene resin, $20 \mathrm{~cm}$ thick, so that the lid was insulating and opaque. For the purpose of observing inside the box, the lid was made easily removable. The toads were fed on earthworms. For adult toads, four to six earthworms, $10-15 \mathrm{~cm}$ in length, were given to each toad every day, and an appropriate number of grubs and insects were also given to them. The juvenile toads were kept in a wooden box $70 \mathrm{~cm} \times 40 \mathrm{~cm}$ and $30 \mathrm{~cm}$ deep. The top of the box was set level with the ground surface, and the bottom of the box was filled to a depth of about $10 \mathrm{~cm}$ with dirt and fallen leaves. The top was covered with wire mesh. Earthworms cut into small pieces and small insects were given to them.

Measurement of environmental factors.Temperature and humidity in the rearing boxes were recorded continuously with an automatic thermometer and hygrometer (IsuzuSeisakusho, Tokyo). During the winter, a stick thermometer was inserted into the location of hibernating animals to measure the ground temperature. Humidity was measured with a hygrometer (Tanita Co., Tokyo) placed in the space where the toads were hibernating.

Recognition of molting.-Following Bendesen (1956), the head of the toad was colored with red lipstick (Shiseido, Tokyo), and molting considered to have occurred when the color disappeared. Skin coloration with lipstick 
did not disappear even after more than 10 days. Judging from preliminary observations carried out in 1983, it seems that molting is more likely to occur between $1500 \mathrm{~h}$ and $2100 \mathrm{~h}$. So observations were made at $700 \mathrm{~h}, 1500 \mathrm{~h}$, and $2100 \mathrm{~h}$ every day. During hibernation, observations were made everyday at $1800 \mathrm{~h}$, by removing the lid for one min. A paired t-test was used to compare molting frequency between sexes.

\section{Results}

Order and process of molting.-An example of molting behavior is shown in Table 1 and Fig. 1. The course of molting took $13-30 \mathrm{~min}$ at 10 $30^{\circ} \mathrm{C}$. As shown in Fig. 2, this period became shorter as the temperature rose (correlation coefficient -0.88 , regression line $\mathrm{Y}=-0.92 \mathrm{X}+33.9, \mathrm{Y}$ denotes time needed for molting, $\mathrm{X}$ temperature ${ }^{\circ} \mathrm{C}$ ). Clear difference in molting behavior was seen among individuals. That is, one male and two female toads always started the process with the skin peeling from the right side of the back, whereas the remaining toad always began molting from the left side of the back.

Molting during the active period (20 May-3 November).-Table 2 shows the incidence of molting in each toad. It shows the tendency for females to have a shorter molting interval than males, and the difference was proved to be signifi-

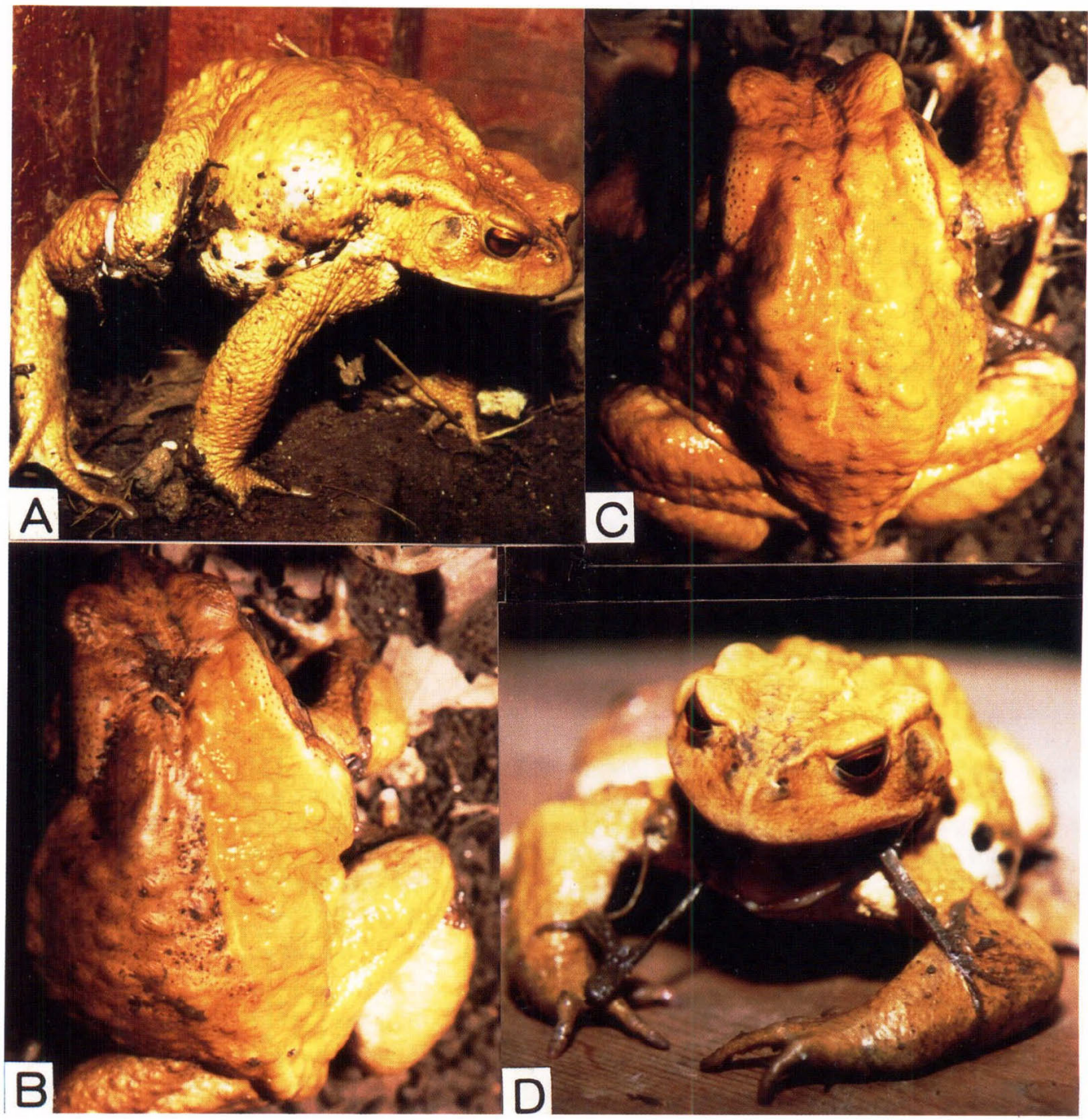

FIG. 1. Actions and course of molting in Bufo japonicus formosus. See Table 1 for explanation. 
TABLE 1. An example of actions and skin surface conditions during the course of molting.

\begin{tabular}{ll}
\hline Time & \multicolumn{1}{c}{ Actions and changes in skin surface } \\
\hline $1815 \mathrm{~h}$ & Toad adopts and unusual posture (Fig. 1A) and stops feeding. \\
$1834 \mathrm{~h}$ & A single rent appears in the skin running along the spine. \\
$1842 \mathrm{~h}$ & Outer skin on the right half of the body peels off instantaneously (Fig. 1B). \\
$1843 \mathrm{~h}$ & Outer skin on the left half of the body peels off instantaneously (Fig. 1C). \\
$1850 \mathrm{~h}$ & Skin peels off from hindlimbs and abdomen. Discarded skin is gathered near the forelimbs. \\
$1851 \mathrm{~h}$ & Toad eats discarded skin while the remainder of skin peels off from the forelimb area (Fig. 1D). \\
$1904 \mathrm{~h}$ & Toad returns to usual posture and resumes feeding. \\
\hline
\end{tabular}

cant by paired t-test $(\mathrm{p}<0.05)$. Figure 3 shows that the molting intervals tended to lengthen with age until eight to nine years after which the intervals stabilized. The mean molting interval of the males was 8.1 days $(\mathrm{N}=2)$ and that of the females $(\mathrm{N}=2)$ was 7.7 days in the four-yr-old toads, and 9.9 days in the males and 9.4 days in the females, in nine-yr-old toads. The shortest period was 4.6 days. In four one-yr-old toads the average interval was $6.4 \pm 0.5$ days $(\bar{x} \pm S D$, $\mathrm{N}=4$ ), and the shortest interval was 3.5 days.

More molting incidents occurred when the minimum daily temperature was $18-23^{\circ} \mathrm{C}$, that is, from mid-June to mid-September. As shown in Fig. 4, when changes in relative humidity exceeded $35 \%$ in the course of a day, toads were twice as likely to molt as on days when the change in humidity was less. As seen in Table 3, $71.6 \%$ of all moltings occurred betwen $1500 \mathrm{~h}$ and $2100 \mathrm{~h}$. The process of molting in immature toads was almost the same as in adults. Notable characteristics of molting in immature toads were shorter intervals and remarkable loosening of the skin prior to molting. The time

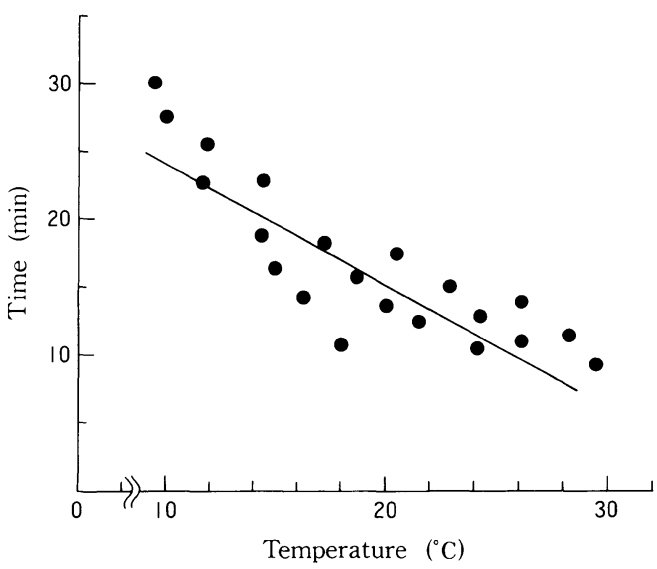

FIG. 2. Relationship between air temperature and time needed for molting. The time becomes shorter as the temperature rises. (correlation coefficient $=-0.88$, Line denote regression line) needed to complete the molting process was about two-thirds that of adult toads.

Molting during hibernation (NovemberMarch).- In adult toads aged eight to 10 years during 1988-1990, molting during hibernation was observed. The total number of moltings was 29 . In the hibernating space $(25-30 \mathrm{~cm}$ below the surface), the average temperature on 20 January was $4.3^{\circ} \mathrm{C}$, and humidity was always higher than $87 \%$. Molting during hibernation, particularly when the ground temperature was $4-5^{\circ} \mathrm{C}$, was very different in its course and timing from that in the active season. That is, unpatterned cracks appeared at various places on the skin, then the outer layer of skin fell off in pieces (Fig. 5), and the molted skin was left on the ground. This molting process took three to four days. The mucus visible on the surface of the new skin was not as pronounced as that during active periods. The toads had one molting by 20 December, and a second one prior to 20 February. In five cases the third molting occurred just before the end of hibernation, but in seven cases this third episode did not happen. Each toad averaged 2.4 moltings during hibernation.

TABLE 2. Incidence of molting in each toad.

\begin{tabular}{|c|c|c|c|c|c|c|c|c|c|}
\hline \multirow[b]{2}{*}{ Toads } & \multicolumn{9}{|c|}{ Year } \\
\hline & 1984 & 1985 & 1986 & 1987 & 1988 & 1989 & 1990 & 1991 & 1992 \\
\hline ô 1 & 20 & 19 & 17 & 16 & 16 & 16 & 19 & 18 & 17 \\
\hline ○ 2 & 19 & 19 & 18 & 18 & 18 & 17 & 17 & 15 & 16 \\
\hline \& 1 & 22 & 21 & 20 & 20 & 20 & 19 & 20 & 20 & 19 \\
\hline ㅇ 2 & 23 & 21 & 21 & 20 & 19 & 21 & 19 & 21 & 21 \\
\hline
\end{tabular}

TABLE 3. Time of day when moltings occurred (1984-1992).

\begin{tabular}{lc}
\hline Time & Occurrence $(\%)$ \\
\hline $700-1500 \mathrm{~h}$ & $65(9.5)$ \\
$1500-2100 \mathrm{~h}$ & $488(71.6)$ \\
$2100-700 \mathrm{~h}$ & $129(18.9)$ \\
Total & $682(100)$ \\
\hline
\end{tabular}




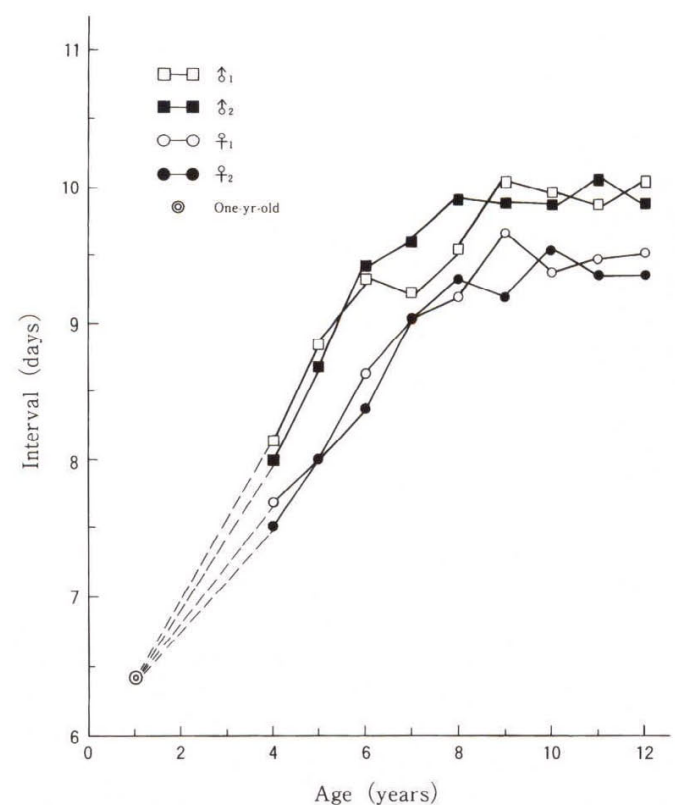

FIG. 3. Relationship between age of the toads and molting intervals.

\section{DisCUSSION}

The influence of temperature on molting observed in the present work largely agrees with the results reported by previous investigators (Bendsen, 1956; Taylor and Ewer, 1956; Scharrer, 1958; Stefano and Donoso, 1964).

It has been reported that molting frequency in adult toads is less than in the growing period of juvenile toads (Bendsen 1956; Jørgensen and Larsen 1961). In the present observations the molting frequency decreased gradually with ag-

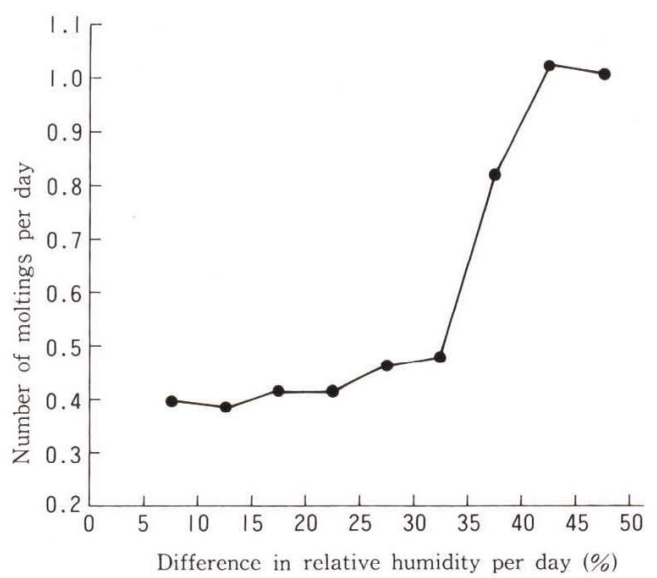

FIG. 4. Relationship between relative humidity difference in a day and the number of moltings.

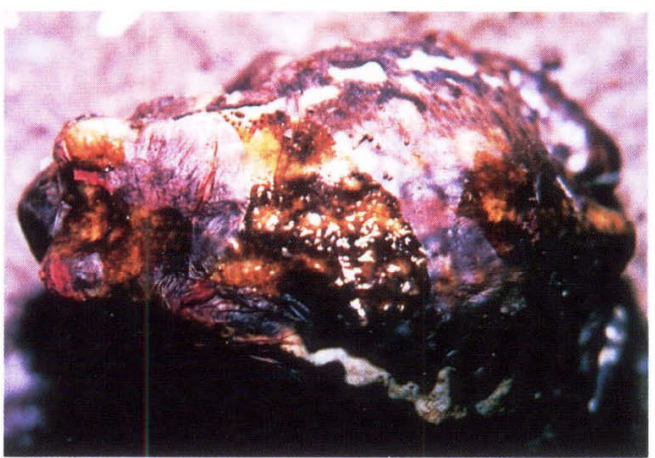

FIG. 5. Molting during hibernation. A series of unpatterned cracks appears over the entire body, and then the skin falls off. Molting requires three to four days.

ing until eight to nine years and then stabilized.

Very little is known about the correlation between the molting and the change in relative humidity in a day. Fundamentally, molting is regulated by hormones (Stefano and Donoso, 1964). As shown in Fig. 4, however, it may be said that the change in relative humidity in a day is one of the effective causes of molting.

Taylor and Ewer (1956) reported that molting frequency is not influenced by body size, age, or sex in Bufo regularis. But sexual difference in molting frequency was seen from May to November. It is clear that females molt more frequently than males.

As far as I know, there are no reports on the molting of toads during hibernation. Larsen (1976) noted that molting occurred even when toads were maintained in a refrigerator at 5$7^{\circ} \mathrm{C}$, when the toads ingested their molted skin. In the present work with a ground temperature of $4.0-5.0^{\circ} \mathrm{C}$, the toads molted, but ingestion was not observed. It is conceivable that the characteristic movements of toads during molting, including the ingestion of skin, is to promote the molting process (Dickerson, 1906), but during hibernation no ingestion of skin was seen in the present work.

Acknowledgments.-This research owes much to the many years of guidance received from Professor Emeritus H. Iwasawa of Niigata University, Professor S. Mizukami of Yamanashigakuin University, and Professor N. Satoh of Kyoto University. Statistical analyses of the data presented in this paper were greatly aided by Dr. T. Hikida of the Department of Zoology, Kyoto University. I express my deep thanks to each of these persons. 


\section{Literature Cited}

Bendsen, J. 1956. Shedding of the skin in the common toad, Bufo bufo. Visdk Medd. Dansk Nat. Hist. Foren. 118 (2): 211-225.

BudTZ, P. E. 1977. Aspects of moulting in anurans and its control. Symp. Zool. Soc. Lond. 39: 317334.

Dickerson, M. C. 1906. The Frog Book. Doubleday, Page \& Co., New York.

Jørgensen, C. B. AND L. O. Larsen. 1961. Molting and its hormonal control in toads. Gen. Comp. Endocrinol. 1(2): 145-153.

JøRGENSEN, C. B. AND L. O. LARSEN. 1964. Further observations on molting and its hormonal control in Bufo bufo (L.). Gen. Comp. Endocrinol. 4(4):

\section{要旨 アズマヒキガェルの脱皮の長期間観察}

\section{田中 達弥}

成体 4 匹を 9 年間屋外で飼育し，脱皮につい て観察した。春から秋までは，脱皮間隔は温度 が高い汪ど短くなり，雌の脱皮間隔は雄に比べ て短かった．加齢とともに脱皮間隔は長くなっ た。脱皮は相対湿度变化が大きい日に起きる
389-400.

LARSEN, L. O. 1976. Physiology of molting. In: B. Lofts, (ed.), Physiology of the Amphibia. III. p. 54100. Academic Press, New York.

SchARRER, E. 1958. Molting cycles in the toad, Bufo marinus. Anat. Rec. 130(2): 369-370. (abstract)

Stefano, F. J. E. AND A. O. Donoso. 1964. Hypophyso-adrenal regulation of moulting in the toad. Gen. Comp. Endocrinol. 4(5): 473-480.

TAYlOR, S. AND D. W. EWER. 1956. Moulting in the Anura: The normal moulting cycle of Bufo regularis Reuss. Proc. Zool. Soc. Lond. 127(3): 461-478.

Katsunuma 3144, Katsunuma-cho, Yamanashi, 409-13 JAPAN

ことが多く，また15時から21時の間に起きるこ とが多かった。成体は冬眠中 2-3 回脱皮した. 別に観察した 1 歳の幼若個体では脱皮回数は成 体に比べて著しく多かった.

(409-13 山梨県勝沼町勝沼3144) 